\title{
Strategy for Competitiveness of Higher Education Use Factor Internal/ External Strategic and Matrix Space Analysis
}

\author{
Syaiful Anwar AB \\ Department of Education, Universitas Bengkulu, Indonesia \\ Received August 4, 2019; Revised May 16, 2020; Accepted May 20, 2020
}

Copyright $(2020$ by authors, all rights reserved. Authors agree that this article remains permanently open access under the terms of the Creative Commons Attribution License 4.0 International License

\begin{abstract}
Higher education is a level of education after secondary education that includes diploma, undergraduate, master's, specialist, and doctoral education programs organized by higher education. Higher education is held in an open system. If the education process in an educational institution is correct, the educational goals will be achieved. If the education process is not correct, it will be difficult to achieve educational goals. The objective of this research is to study the capacity of Islamic Institute of Bengkulu State in improving competitiveness of higher education (Study of Policies at Islamic Institute of Bengkulu State, Indonesia). The data consist of the policy effective at The State Islamic Institute Bengkulu, Indonesia from 2013 to 2016. Analysis tool used is the SWOT analysis by calculating the strengths, weaknesses, opportunities and threats. The study shows the functioning of market segmentation strategy, targeting strategy, positioning strategy, differentiation, focus and efficiency as element the competitive power at The State Islamic Institute Bengkulu. This confirms the importance of applying a total quality management system for enhanced health of the organization a higher educational institution. The contribution of this research is aimed at university managers to increase competition and the achievement of missions and missions, it is necessary to encourage the improvement of lecturer qualifications with further education, learning activities, research and community service with adequate facilities and budget funds so that the quality of resources can be improved so that it will automatically encourage improvement in the quality of education in higher education.
\end{abstract}

Keywords Competitiveness, Strategic and Higher Education

\section{Introduction}

The college is an institution that has a role and strategic position within the education goals, Therefore, efforts should be made continual improvements to realize the quality of human resource [1], [2], [3] \&[4]. Leaders who have an insight into the future become an important determinant in transforming the strategic changes in order to bring about an environment that supports the college through the establishment of "corporate culture" grade for education. Therefore, it needs to support efforts to increase the competitiveness of universities in the arena of increasingly fierce competition, particularly nuanced religious colleges. Internally there are three challenges faced by higher education, namely, (1) challenges in curriculum changes that are intended to prepare students to enter the technological age, (2) a challenge due to limited resources to support change and (3) the challenge of providing learning opportunities more widely. The most important change that needs to be done is the change of organizational culture on leadership style [5], [6] \& [7]. Selection of leadership style approach can be a colleague's leadership, bureaucratic, and cooperative enterprise. Collegial leadership is the most appropriate for universities. Organizational culture is a system of shared meaning held by members that distinguishes the organization with other organizations [8] \& [7]. The changes facing higher education demand response is not comprehensive, but more fundamental response, that response to make a paradigm shift. Paradigm changes also mean a change in the mental attitude of the institution where the college is located [10]. It should be noted, that in any rapid change due to technology, the gap between the common attitude that should occur with real attitude. This occurs due to a change of mental attitude which is closely related to the cultural change that takes receipt longer than the technology itself changes [11]. State Islamic Institute 
(IAIN) in the last decade the face of the huge challenges that the emergence of new colleges were more aggressive. Bengkulu province including the provinces of just escaped from southern Sumatra in 1968 with a population of 1.73 million inhabitants. The number of universities today is seventeen universities. Relatively old college is UNIHAZ, UNIB, UMB, UNIVED, health sciences colleges are amount of seven universities. College competitors as the market leader is the University of Bengkulu, Challenger markets are from Muhammadiyah University, UNIHAZ, Dehasen university colleges within the city. College health field are domiciled in the city of Bengkulu and in the district. So, IAIN in the last three years experienced a very significant challenges due to the growth of higher education, especially college health sector in the province of Bengkulu.

Therefore, IAIN needs to make strategic changes to compete in the face of fierce competition. For a college that is based on religion and as a result of the times, advances in information technology a decline in interest in education based on religion. Then there is the threat of a shift in values that the employment of graduates is limited. That new student input is a driving force of the organization. Therefore, based on this fact IAIN should reevaluate, make changes in all fields. Changes people in the organization include changes in: (1) a policy of withdrawal and selection; (2) the development of training activities; (3) The system of remuneration; (4) leadership skills and managerial communication; (5) the attitudes, beliefs, roles and characteristics of other employees. Furthermore, changes in higher education aimed at changing the system, teaching, research, management and business matters, and changing relations with others [12]. A key factor for university development strategy is a college environment change, the structure of the academic, research, teaching and learning as well as managerial university. Furthermore, to be considered by the leadership is academic excellence, speed of response, collaboration through partnerships, appropriate investment in infrastructure, and the highest quality staff [13]. Literally understanding of strategic management, according to the [14] explains that: Strategic management is the set of managerial decisions and actions that determines the long run performance of a corporation. From this sense it can be said that strategic management is a series of decisions and actions that have a long-term range to achieve the performance of a business or organization.

Empirically many organizations fail to achieve the objectives journey. This is caused by the inability to implement strategic management concepts well. Implementation of the concept of strategic management is the organization must prepare a strategic plan. Strategic planning is a form of long-term planning, medium and short that covers vision, mission, goals, strategies, programs and activities of the organization [15]. Furthermore, the usefulness of strategic planning are: (1) provide better guidelines for all levels of the organization about the crucial point what they're doing; (2) make managers more cautious about change, new opportunities, and the development of the threat; (3) gives the manager the reasons that make sense regarding resource allocation priorities of the organization; (4) to help integrate the various decisions relating to specific strategies undertaken by various managers in various fields within the organization; and (5) creating a management attitude that is more reactive than being defensive or reactive that sometimes it is too late.

The strategy is not only required by an organization that focuses on profit-oriented only, but also for non-profit oriented, such as hospitals, universities, churches, governments at various levels, religious institutions, libraries and other social institutions [16]. Some research indicates that organizations that have a clear strategy or formal will be superior performance (out performed) as compared to organizations without or not Formulated with a clear strategy [17]. Globalization and the changing demands of customer demand requires management IAIN Bengkulu to move forward following the change was, in addition, Islamic colleges need to do repositioning among universities in Bengkulu. That is, the determination of the new position and orientation of the new paradigm. Repositioning colleges conducted by examining all the strengths, weaknesses, opportunities and threats, so that it can be determined the things that must be improved and strengthened. Then, do the portrayals of consumer who, who's producing the products/services, replacement services and who is there any new entrants in the business. Each college, anyone who produces graduates certain courses, is there a replacement product programs offered? who the new arrivals in certain courses [18] \& [19]. The quality of higher education is a dynamic condition related services, labor, and environmental processes and tasks that meet or exceed customer expectations [20]. Tastes and expectations of consumers at a university is always changing, so the quality of services must also be changed or adjusted.

How to evaluate the quality of higher education services? First, the direct evidence (tangibles) include physical facilities, equipment, employees, and means of communication. Second, the reliability (reliability) the ability to provide the promised services promptly and satisfactorily. Third, responsiveness (responsiveness), namely the desire of the staff to help customers and provide service with a response. Fourth, assurance (assurance) that includes the ability, courtesy and trustworthiness owned by the staff, free from danger, and the risk or doubts. Fifth, empathy (Empaty) including ease in the relationship, good communication and understand the needs of customers [21]. Build the impression of higher education should start from the development of quality or reputation of the degree program (undergraduate), graduate (graduate Programmes), foreign 
students (overseas students), the relationship with the industry and the world of work, earn income generating and then get a positive image or reputation of the college high [22].

Furthermore, what are the merits College? Services colleges are science, education, and scholars where science and the results were. Who Higher Education customers are students, parents, institutions and agencies other users. Customers consist of customer primary, secondary, and tertiary customers [23]. Quality improvement can be seen on the achievement of academic and non academic skills higher that enable graduates to be proactive to changes in society in various fields both locally, nationally and internationally. In order to improve the quality of higher education, it is necessary to nourish the quality of its research effort and improvement of learning and teaching process, so as to increase the competitive ability of higher education institutions in Indonesia [24]. Furthermore, [25] [26] say that quality improvement and the quality of higher education graduates is highly dependent on the input of students, educators, facilities and infrastructure that existed at the college in question and depends also frame input, process and output steady.

Measuring the success of a university according [27] it is said there are several factors that must be seen in the measurement of success include the quality of incoming students at the university, the ratio of lecturers to students, the level of time spent student at the library, the facilities available, the level of classification and graduation rates, quality of research, as well as between research and teaching activities are in balance. Law No. 20/2003 on the National Education System chapters 57, 58, 59, and 60, described that quality control or also known as quality assurance implemented towards education units, including in universities. based on religion. These aspects are important quality assurance implemented are (1) the evaluation of learners and institutions; (2) accreditation for determining the eligibility of programs and education units; (3) certification to demonstrate competence to learners in doing any work. Accreditation acquired unit or course declare the value of the dignity of the quality of the institution concerned. Therefore, the National Accreditation Board of Higher Education [28] \& [29] establishes criteria for healthy and quality tingggi college is accredited college.

The paradigm of higher education management concerning quality components, autonomy, accountability, accreditation and evaluation, presented a note as follows: Quality is a moving target, so in any particular period need to set benchmarks for each college, which in turn leads to quality standards high [30]. Interest Benchmarking is to identify and test various innovations, as well as the best application to direct the key to the success of universities in the development process management [31]. SWOT analysis in tertiary institutions is used in preparing work and strategic plans. The work program was developed by analyzing Sterngth, Weakness, Opportunities, and Threats (SWOT) of the internal and external conditions of the university concerned.

Mission traditional system of higher education is to educate, conduct research, and provide services to the communities remain valid, confirmed that their primary mission today is to educate the population to being responsible to provide open space for higher education and for lifelong learning [32]. How to see the relevance of higher education as a means of competing universities in Indonesia?. Relevance can be applied if we change the approach of the college. If still maintains a "deal" then during the same relevance is not reached. Relevance can be realized if the college Indonesia has shifted to a "request". That is, the course opened and closed in accordance with market demand and relevance of what is called quantitative relevance. Linkage studies, is related to the world of work itself. The world of work is where all human beings are capable of acting to find herself, develop career abilities, to actualize itself in social life and achieve optimal value of life compatible with the competencies required. That is achieved by means of linkage is a qualitative suitability. The second kind of relevance is a shape shifting consumer demands college, and it is because there are global pressures that require stakeholders colleges are looking for forms of appropriate marketing strategy to come out winners. That is, the acceptable output (Alumni) a college by the world of work means the better the reputation of the college.

\section{Literature Review}

\subsection{University Reform}

Sheila [33] conducted a study on university management reform in the US, United Kingdom, Canada, and Australia asking questions:

"What is the scope of economic change that characterizes the last quarter of the twentieth century and how does it affect higher education? We have moved from an industrial to a postindustrial society and higher education is more important to the latter. Postindustrial societies depend on higher education for training and research and development $(R \& D)$ to a greater degree than do industrial societies.

In the last decade change the world starting from the change in the college. Development of the industry depends on the university. for universities conducting trainings, research and development. Real conditions in Indonesia it has not been possible to match the developed countries in the world. Although the Higher Education and Ministry of Religious Affairs has adopted a policy directing universities in Indonesia to arrive at a parallel level with universities in the world (World Class 
University). Efforts to develop the relevance and competitiveness in higher education is shown by the independence of the learners who would become alumni [34]. This can be done by growing independence, encouraging the growth of the attitude of the entrepreneur or entrepreneurial students and alumni. Conceptually, the organization of college-oriented entrepreneurship is a synthesis-oriented education system human investment.

\section{Materials and Methods}

Model diagnosis offered is a self-evaluation by the approach of evaluating policies that have been taken during the period 2013-2016. By using the method of analysis of the strengths, weaknesses, opportunities and possible threats (SWOT), developing a competitive strategy of what to do in winning the ranks of competition in the services colleges especially the State Islamic University of Bengkulu, so it can compete nationally and internationally. SWOT analysis tools at universities follow research conducted by [42], [43] and [44].

\section{Result and Discussion}

\subsection{Result}

In the face of college competition, it is required to set the vision and mission as well as having strengths, weaknesses, opportunities and threats. To that end, Bengkulu State Islamic Institute (IAIN abbreviated Bengkulu) as a state Islamic universities in Indonesia Bengkulu, hould clarify its position in the competition. The college is a further development of the Faculty of IAIN Raden Fatah, which is then converted into a high school Islamic country. Since the year 2012, changed its status to Bengkulu STAIN Islamic Institute, Presidential Regulation No. 51, dated 25 April 2012 at Raden Patah, Pagar Dewa, the city of Bengkulu, Indonesia. [35].

\footnotetext{
Vision Mission IAIN Bengkulu

Vision

"Excellence in Islamic studies, science and entrepreneurship"

Mision

1. Develop Science - Islamic Sciences, Science and Entrepreneurship in education and teaching to improve the quality of research and dedication that are responsive to the interest science and society.

2. Improve the quality of student character, professional, independent and noble.

3. Develop a system of education and quality learning that is based on science and technology.

4. Build partnerships with various parties to improve the quality of Tri Dharma College.
}

One of the tools to compete universities at this time other than the determination of its vision and mission, the dignity of accreditation becomes important competitive tool., Institute of Islamic Bengkulu now obtain the dignity Accreditation is B. The study program can be seen below:

Ahwal Al-Syaksyiah (S1) (Accreditation A) (Valid until 03-09-2020) (Status valid) 2. Morals and Mysticism (S1) (Accreditation C) (Valid until 08-08-2019) (Status still valid). 3. Arabic Language and Literature (S1) Accreditation C, Valid until 18-06-2019, status still valid. 4. Bimbingan and Counseling Islam (S1) Accreditation B Valid until 22-06-2020. 5. Constitutional Law/Siyasah (S1) Accreditation C Valid until 28-02-2020. 6. Science Qur'an and Tafseer (S1) Accreditation B is valid until 30-05-2020. 7. Communication and Broadcasting Islam (S1) Accreditation B Valid until 10-07-2020. 8. Propagation Management (S1) C Accreditation is valid until 29-08-2019). 9. Muamalah (S1) (Accreditation B) applies to 28-03-2020.10. Islamic Education (S1) (Accreditation) is valid until 07-02-2020. 11. Education Arabic (S1) Accreditation is valid until 02-05-2020 .12. Teacher Education Madrasah Ibtidaiyyah (S1) Accreditation B is valid until 02-05-2020). 13. Teacher Education Raudlatul Athfal (S1) Accreditation C apply to 23-10-201. 14. Islamic Banking (S1) C Accreditation is valid until 07-12-2019. 15. History and Culture of Islam (S1) C Accreditation is valid until 28-12-2019. 16. Zakat and Waqf (S1) C Accreditation is valid until 09-01-2020. 17. Philosophy of Religion (S2) Accreditation is valid until 08-08-2019 C (IAIN Profile, Bengkulu 2016).

Land campus today is 73 hectares largely been established Class buildings, library, hall, mosque, and Space Dean. Currently the facilities and infrastructure building complete with furniture. To support physical means, then the non-physical such as lecturers and employees is very important; Lecturer consists of master 234 people, doctor 35 and a professor 3 people. Number of employees 103 people (Civil Servant) Non Civil Servants 45 people and 31 contract employees. The number of students is as many as 9152 people [35].

State Islamic Institute Bengkulu face a tough challenge, faced with competition in the college ranks in Bengkulu. The college market is getting narrower, because the number of universities from time to time increases. In the face of competition [18] \& [36] reveal a business or non-business organizations have to see who the new arrivals, who are already on the market, the consumer is there and is there a product / service replacement. There are seventeen universities in Bengkulu. College health sector there were seven then there are two public health faculties at public universities, namely the University Muhamadiyah and UNIVED. Therefore, IAIN. knowing that the labor market was opened by the government are paramedics and teachers. Therefore, the community colleges interested in opening the health sector became the biggest competitor IAIN. While weakness is still inadequate IAIN Institutional 
accreditation of new B and many courses are accredited C and $\mathrm{B}$, and only three (3) accredited institution A. It is the people that choose a college based on the dignity of the quality seen by the people is the dignity of accreditation BAN PT.
Based on the information that can be collected, IAIN wants to improve their competitive ability, it is necessary to scan the strengths, weaknesses, opportunities and threats. Table 1 and Table 2 presents the performance of the following conditions.

Table 1. Factor Internal Strategic

\begin{tabular}{|c|c|c|c|}
\hline Factors Internal strategic & Weight & Rating & Score \\
\hline Strength & & & \\
\hline Management experience & 0,15 & 4 & 0,60 \\
\hline High Management Commitment & 0,10 & 4 & 0,40 \\
\hline High Number of Alumnus & 0,10 & 3 & 0,30 \\
\hline Total, experience, and good quality employees & 0,15 & 4 & 0,60 \\
\hline Locations in Central City & 0,10 & 4 & 0,40 \\
\hline Infrastructure of Building is Good & 0,10 & 3 & 0,30 \\
\hline Amount & 0,65 & & 2,30 \\
\hline Weakness & & & \\
\hline Qualification of Professors Limited & & & \\
\hline Spread faculty workload unevenly & 0,10 & 2 & 0,20 \\
\hline Development of lecturers and employees limited & 0,05 & 1 & 0,05 \\
\hline The number of students is relatively small & 0,05 & 1 & 0,05 \\
\hline T. Ability to Compete gap between Program & 0,05 & 2 & 0,10 \\
\hline Amount & 0,05 & 2 & 0,10 \\
\hline Total & 0,05 & 3 & 0,15 \\
\hline Matriks Space & 0,35 & & 0,65 \\
\hline
\end{tabular}

Sources: Data Process (2018).

Need to be analyzed and displayed on external factors that can influence policy and decision IAIN competitive strategy, presented below in Table 2.

Table 2. Factor External Strategic

\begin{tabular}{|c|c|c|c|}
\hline Factors External Strategic & Weight & Rating & Score \\
\hline Opportunity & & & \\
\hline to provide development opportunities Studies Program & 0,15 & 3 & 0,45 \\
\hline $\begin{array}{c}\text { The availability of lecturers and employee for opportunities } \\
\text { development }\end{array}$ & 0,15 & 3 & 0,45 \\
\hline Availability of Institutional Development Opportunity & 0,15 & 4 & 0,60 \\
\hline Have many number of high school graduates & 0,15 & 3 & 0,45 \\
\hline Amount & 0,60 & & 1,95 \\
\hline Threat & & & \\
\hline The high development of other universities & 0,10 & 3 & 030 \\
\hline Job Opportunities for graduate are restricted & 0,05 & 2 & 0,10 \\
\hline Human resource competency (Alumnus) requested higher & 0,05 & 2 & 0,10 \\
\hline Capability for Publications of Lecturer is still Low & 0,05 & 2 & 0,10 \\
\hline Interesting of candidates to choose IAIN is still low & 0,05 & 2 & 0,10 \\
\hline Amount & 0,40 & & 0,70 \\
\hline Total & 1,00 & & 1,65 \\
\hline Matriks Space & & & 1,25 \\
\hline
\end{tabular}

Sources: Data Process (2018). 
SWOT Analysis, Internal values obtained (IE) 1.65 and 1.25 means that external conditions IAIN development are at the Growth and Stability. Internally variables give a positive signal or a powerful force in the development of IAIN remaining strength of 0.40 points. Factors which provide opportunities for the development of IAIN also show a positive value or is still larger than the factors that threaten the sustainability of development IAIN. Therefore an appropriate strategy to be applied in the development of IAIN in Bengkulu City is the offensive strategy. Analysis of the Space Matrix approach is graphically presented in Figure 1. There is a consistency between the two approaches is better to use Matrix Internal and External (MIE) and Matrix Space (MS) and both support the Stability and Growth Strategy offensive. It can be seen in the following Figure 1 as a follows:

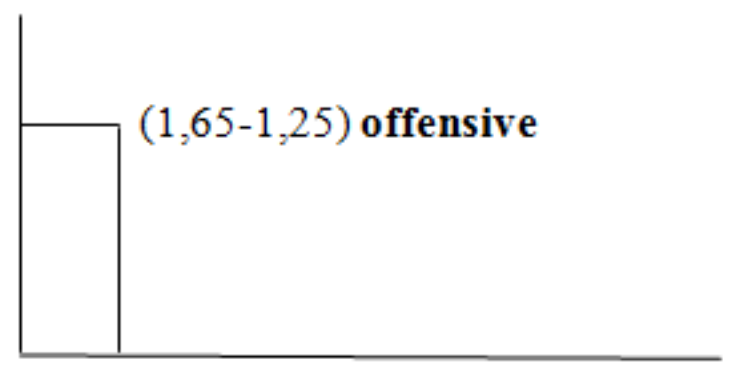

Figure 1. Matrix Space Analysis

Based on Figure 1, The Matrix Space Analysis (MS) obtained a value of 1.65 to 1.25 for the $\mathrm{X}$-axis and $\mathrm{Y}$-axis indicates that the conditions IAIN development was on the offensive. Factors that provide signal strength of IAIN development with a positive value is still larger than the debilitating factors. Therefore, an appropriate strategy to be applied in the development of IAIN Bengkulu is a strategy that is to think fast, move fast and accurate analysis. Can be explained offensive strategy used so that an excess of factors into strengths, supporting and giving opportunities in the development of Islamic Institute State of Bengkulu (IAIN) be pursued so that the optimal acceleration IAIN growth can be realized in the not too long.

\subsection{Discussion}

Growth and stability development strategy of colleges require the preparation of a direction and strategy with the involvement of various stakeholders. Meanwhile, with the mandate of the Medium Term Development Plan, Vision and Mission of Rector until 2018 that IAIN to be campus of "Excellence in Islamic studies, science and entrepreneurship". Islamic Institute of Bengkulu State as a place to seek community activities and sets the selection of science and knowledge, need to be pushed to the equal opportunity to obtain higher education is good and ultimately increase public welfare, along with the increasing level of public education.
In addition, the central government has committed to developing strategies and policies for the development of higher education in Indonesia based on the principle of legal certainty, transparency, accountability, equal treatment and did not distinguish the origin country, togetherness, efficiency and justice, sustainable, and environmentally friendly, self-reliance, as well as the balance between progress and achieve integrity of the Republic, with the principle of equality and not to drop mainly perpetrator major colleges (strong) to small colleges and eliminate disparities quality. On the basis of the description above, policy development of Islamic Institute of Bengkulu State relies on diversification and differentiation, focus and lower costs [18] \& [37]. Furthermore, the Government focuses on three main strategic objectives. All three objectives are (i) Health Organization; (ii) Financial Restructuring (iii) restructuring of competitiveness;

The participation of the users and customers of other tertiary colleges of great significance for the implementation of the marketing strategy of Islamic Institute of Bengkulu State. People who care about the college (Moslem) are very rare. Therefore, it is necessary to find the model and the best way to communicate with the business world, the people concerned and the local government so that there is good cooperation, so as to mutually utilize their resources. The higher the level of participation of people who are interested in the institution of higher learning, the better the managerial level of the universities. The higher the participation of entry, meaning the higher the competition. So the Islamic Institute of Bengkulu State will get input prospective students a high enough level (grade) and its value.

Rector and his staff continue the policy by arranging various marketing strategies for the Islamic Institute of Bengkulu State as follows: Diversification strategy, this strategy is done by creating a lot of activities, for example, creating a non-degree programs varied, managed by a professional, using the principles of continuous quality, and opened in accordance with market needs. The program appears on studies need accurate. Thus, the college does not contribute to the creation of disguised unemployment. Here is one form of accountability to the community college. This means that the courses offered "gayut" to the needs of existing employment. In a focused strategy, arranged in order of the many activities that there are certainly no underdog; whether the program of study that is superior (diploma or undergraduate), or whether the research is seeded, depending on the resource that belongs to the college. Publication and use by the user is still low. Therefore, it is necessary to find a new strategy to accelerate the improvement of scientific publications, as a tool to compete in this global era. Currently IAIN try to encourage a focus on language courses, preaching and the Tarbiyah. The reason is opportunity. Working for alumni still open to fill the religious teachers. 
Low cost strategy, goes to college to be impressed cost. Of course with the efficiency and budgetary discipline as well as seeking "income generating" multi source. This means that universities need to think about their real sector managed by this institution that serves as a Strategic Business Unit of Islamic Institute of Bengkulu State. What about college like IAIN? certainly very possible, because resources for the purposes of highly available. This strategy will help fund IAIN. If IAIN impressed low cost, then the public will turn to this college. Higher education can not create cheap. but local governments have contributed creates cost of living and accommodation should be impressed low cost, and this is also the role of government to create an attraction for the region.

Segmentation Strategy, which began in the strategy focus. This means that universities should focus on one or two excellent courses, then that is where the intended market segment. For example, we know the student input is low, then we create a new segment by building and developing the Laboratory Schools, sure gait Tarbiyah and Sharia IAIN be the center of activities/strategic business unit for Islamic Institute of Bengkulu State. The study program featured an option, in carrying out their duties should receive greater attention, including funding for the flagship building. No more barriers to a flagship program, it is in the interests of greater IAIN forward. Facing increasingly intense competition in the arena of higher education in the global era. From the observations and the data that are available today tendency that course is a course of Tarbiyah and Sharia that supported by economic department. Targeting strategy, this strategy needs to be developed. The Islamic Institute of Bengkulu State must define performance targets solving existing problems. Target attainment how many students must be accepted to cover the operating costs of colleges and implementation of the learning process. Onwards, calculated how much income generating that can be assembled to assist the financing in question. Looking for a variety of funding sources are indispensable in the future. For that, we need creative leaders in this field. Thus the best hope lies in the models of mutually beneficial cooperation, and most likely to make healthy financially the Islamic Institute of Bengkulu State.

Strategy positions can be done also with a view on how the study program get A accredited. Currently, the program of study that can improve the position of IAIN are Tarbiah, Sharia because because this program dignity akareditasinya A. Then compare it with the existing universities in the region and Sumatra. From the position of the dignity of the value of accreditation can be seen and determined the position of the Islamic Institute of Bengkulu State on the order of how the ranks of competition in the area of higher education services and Sumatra.

Determination of the competitive strategy of Islamic Institute of Bengkulu State, are necessary commitment to quality, relevance, competitiveness, improvement of systems and processes, leadership, participation of all concerned [38], [39], [40], [41], [42] \& [43]. If you have pursued would have communicated with customers both primary and secondary customer or ertiary customer (workplace). Promotional tools should also be used, so that the audience knows gait, the performance and the existence of the Islamic Institute of Bengkulu State. Competitive strategy strong college is college combines segmenting, targeting, positioning, differentiation, focus and low cost strategy [44], [45], [46] \& [47]. On the other hand, have the courage to campaign on relevant websites, and people can easily access them. Only what is needed is the willingness of managers and stakeholders for community colleges.

Looking ahead, the independence of the funding will determine the sustainability of the competitive strategy of Islamic Institute of Bengkulu State, especially to meet the campus management autonomy. Internal fund raising, with the old ways would no longer tenable. That is, the funds raised by selling the excess capacity of basic services to students and service development of science and technology (research), as well as build business units/strategic services. The era of openness is an era of information technology. Now the extent of Islamic Institute of Bengkulu State to be able to utilize this technology for marketing purposes colleges, especially for the promotion of the digital world. The requirements to be included in digital promotions are college should set up hardware and software. Then, the most important is the management's commitment to the promotion of the content. That is, the content of the promotion should not contain things that are not consistent with the fact that there is in college concerned.

\section{Conclusions and Suggestion}

\subsection{Conclusions}

1. Good competitive strategies are encompass quality, relevance and sustainability of college;

2. In determining the strategy needs to implement an integrated system of internal management and dare to innovate and responsive to changes in sustainable manner;

3. To realize the independence of funding, universities should need to innovate in access to sources of funding;

4. Mix marketing strategies of Islamic Institute of Bengkulu State that can be selected are segmentation, targeting, positioning, differentiation, focus, or low cost strategy.

\subsection{Suggestion}

Offensive strategy, Islamic Institute of Bengkulu State 
should increase its promotional mix in a variety of media, enter the dignity and value of accreditation featured capabilities, both in academic and scientific development of national and international work, dedication to the community and the strengthening of the entrepreneurial spirit of students.

\section{REFERENCES}

[1] Buchari Alma, (2004). Marketing Management and Marketing Services, Alfabeta, Bandung.

[2] Lust, M., Huber, C., \& Junne, J. (2019). Academic identity as a discursive resource for resistance: the case of quality management in German higher education institutions. Higher Education Policy, 32(1), 49-69.

[3] Schwartz, K., Cappella, E., \& Aber, J. L. (2019). Teachers' Lives in Context: A Framework for Understanding Barriers to High-Quality Teaching Within Resource Deprived Settings. Journal of Research on Educational Effectiveness, 12(1), 160-190.

[4] Stachová, K., Papula, J., Stacho, Z., \& Kohnová, L. (2019). External partnerships in employee education and development as the key to facing industry 4.0 challenges. Sustainability, 11(2), 345.

[5] Dopson, S., Ferlie, E., McGivern, G., Fischer, M. D., Mitra, M., Ledger, J., \& Behrens, S. (2019). Leadership development in Higher Education: A literature review and implications for programme redesign. Higher Education Quarterly, 73(2), 218-234.

[6] Dalimunthe, D.M.J., \& Muda, I. (2017). The Empirical Effect of Education and Training to the Performance of Employees. International Journal of Economic Research. 14(21). 403-413.

[7] Sousa, M. J., \& Rocha, Á. (2019). Leadership styles and skills developed through game-based learning. Journal of Business Research, 94, 360-366.

[8] Sweeney, A., Clarke, N., \& Higgs, M. (2019). Shared leadership in commercial organizations: A systematic review of definitions, theoretical frameworks and organizational outcomes. International Journal of Management Reviews, 21(1), 115-136.

[9] Warner, David and David Palfreyman (1996). Higher Education Management: The Key Element, SRHE and Open University Press. Buckingham.

[10] Robbin., P. Stephen. , (2002). Organizational Behavior, PT. Index of Gramedia Group, Jakarta.

[11] Sutjipto, (2002). Challenges, Policies and Management of Higher Education: Implications of IKIP Transformation Becoming a University, Speech inaugural Professor of State University of Jakarta.

[12] Bargh, Catherine. (1996). Coverning University: Changing the culture, SRHE, and Open University. Buckingham.

[13] Chris Duke, (2002). Managing The Learning University,
SRHE and Open University Press, Ballmoor, Buckingham.

[14] Scott, Peter, (2000). Higher Education Re-Formed, Falmer Press. London.

[15] Teece, D. J. (2019). A capability theory of the firm: an economics and (strategic) management perspective. New Zealand Economic Papers, 53(1), 1-43.

[16] Rumble, G. (2019). The planning and management of distance education. Routledge.

[17] Steiss, A. W. (2019). Strategic management for public and nonprofit organizations. Routledge.

[18] Wu, H. (2019). Three dimensions of China's "outward-oriented" higher education internationalization. Higher Education, 77(1), 81-96.

[19] Porter .E Michael, (1980). Competitive Strategy: Techniques for Analiyzing Industries and Competitors, The Free Press, Macmillan. New York.

[20] Kotler, Philip, (2000). Marketing Management, PrenticeHall, Inc, New Jersey, USA.

[21] Sallis, E (1993), Total Quality Management in Education, Pheladelphia. London.

[22] Croonen, E. P., \& Broekhuizen, T. L. (2019). How do franchisees assess franchisor trustworthiness?. Journal of Small Business Management, 57(3), 845-871.

[23] Shattock, Michael, (2004). Managing Successful Universities, Open University Press, McGraw, Hill. USA.

[24] Indrajit, R. Eko and R. Djokopranoto, (2006). Moderen Higher Education Management, Andi Offset, Yogyakarta.

[25] Tilaar, H.A.R, (2004). New Paradigm of National Education, PT. Rinike Cipta, Jakarta.

[26] Sofyan, (2016). Education Quality Improvement Strategy in Higher Education. Hunafa Journal. 3(3). 319 -326.

[27] Asmawi, M. Rosul. (2016). Strategy to Improve Quality Graduates in Higher Education, Journal of Makara Sosial Humaniora, 9(2). 66- 71

[28] Umbach, P. D., Tuchmayer, J. B., Clayton, A. B., \& Smith, K. N. (2019). Transfer student success: Exploring community college, university, and individual predictors. Community College Journal of Research and Practice, 43(9), 599-617.

[29] Hutagalung, B.; Dalimunthe, D.M.J, R., Pambudi, \& A.Q. Hutagalung I. (2017). The Effect of Enterpreneurship Education and Family Environment towards Students' Entrepreneurial Motivation. International Journal of Economic Research. 14(20). 331-348.

[30] Anonymous, (2005). New Higher Education Development Policy. DIRJEN-DIKTI, Jakarta.

[31] Anonymous, (2007). National Accreditation Board of Higher Education, DEPDIKNAS, Jakarta.

[32] Lyons, K. (2019). Social work in higher education: Demise or development?. Routledge.

[33] Allen., Mark, (2002), The Corporate University Handbooks: Designing, Managing, and Growing a sucessful Program, 
Amacom. New York.

[34] Jarvis, Peter,(2001). Universities and Corporate Universities, Kogan Page Limited. London.

[35] Slaught, Sheila, and Larry L.Leslie, (1997). Academic Capitalism: Politics, policies, and Entreupeurnerial University, The John Hokins University Press. Boltimore.

[36] Zong, X., \& Zhang, W. (2019). Establishing world-class universities in China: deploying a quasi-experimental design to evaluate the net effects of Project 985. Studies in Higher Education, 44(3), 417-431.

[37] Anonymous, (2016). Profile of the State Islamic Institute of Bengkulu, Bengkulu.

[38] Grimm, J., \& Gilbert, D. U. (2019). Gaining Mutual Benefits Through Business-non-profit Partnership in Base-of-the-Pyramid Markets: A Relational View. In Corporate Social Responsibility and Corporate Change (pp. 177-203). Springer, Cham.

[39] Marini, A, Safitri, D \& Muda (2018). Managing school based on character building in the context of religious school culture (Case in Indonesia). Journal of Social Studies Education Research. 9(4). 274-294.

[40] Wheelen, Thomas L. and J.David Hunger, (2002). Strategic Management and Business Policy, 8th edition, Prentice Hall.

[41] Jarvis, Peter, (2000). University Leadership :The Role of chief Executive, SRHE, and Open University.
Buckingham.

[42] Allen, D. S., Wood, A. J., Sponberg, E., \& Arnold, T. M. (2019). Digitally Mediated Supervision: Redefining Feedback Systems in Field-Based Courses. In Handbook of Research on Field-Based Teacher Education (pp. 542-564). IGI Global.

[43] John M. Bryson, (2004). Strategic Planning for Public and Nonprofit Ortganization: A Duide to Strenghening and Sustaining Organizational Achievment, John Wley \& Sons.

[44] Seijger, C., Hoang, V. T. M., van Halsema, G., Douven, W., \& Wyatt, A. (2019). Do strategic delta plans get implemented? The case of the Mekong Delta Plan. Regional Environmental Change, 19(4), 1131-1145.

[45] Phadermrod, B., Crowder, R. M., \& Wills, G. B. (2019). Importance-performance analysis based SWOT analysis. International Journal of Information Management, 44, 194-203.

[46] Wang, X., \& Zou, Y. (2019, April). SWOT Analysis of Clinic-style Legal Education in China. In 3rd International Conference on Culture, Education and Economic Development of Modern Society (ICCESE 2019). Atlantis Press.

[47] Vishnevskiy, K., Calof, J., \& Meissner, D. (2019). Corporate foresight and roadmapping for innovation in Russia: A joint university corporate experience. In Futures Thinking and Organizational Policy (pp. 157-176). Palgrave Macmillan, Cham. 